\title{
The Nigerian Child and National Development: A Philosophical Appraisal
}

\author{
Okafor, Paschal Somuadina
}

\author{
School of Education \\ Federal College of Education (Technical), Umunze-Anambra State, Nigeria
}

Nnubia, Uju E

Department of Home Economics, Federal College of Education (Technical), Umunze-Anambra State, Nigeria

\section{Doi:10.5901/jesr.2013.v3n4p103}

\begin{abstract}
The Nigerian child: a philosophical appraisal focuses on defining the Nigerian child. It highlighted the characteristics, concepts and appraisal of the Nigerian identity culminating to the establishment of the Nigerian identity as a 'Being - With'. It was observed that poverty, politics, negative value system and civilization led to the loss of the Nigerian identity. It was recommended that Nigerians should re-understand themselves as 'Being-with' that is meant to live with others and together there will be better development.
\end{abstract}

\section{Introduction}

Nigeria as a geo-political entity was a direct product of the mechanical amalgamation of the Northern and Southern protectorates in 1914. It is a nation of close to 260 nationalists with different histories and cultures. In fact, much has been said and written about Nigeria, her people, culture, economy and politics which sheds lights to a seemingly emerging giant from the third world countries. But Nigeria seems not to have equipped herself with self-knowledge and selfunderstanding to direct herself for better development. This self knowledge and understanding begins with birth, i.e. a Nigerian child who with better understanding of self will have a directed development aligned with his/her identity. The question then is who is a Nigerian child?

\section{Characteristics of a Nigerian Child}

The Nigerian Child refers to that young human being between the birth and puberty who grows into a fully fledged man or woman with time. The child has the right to life, dignity of human person, personal liberty, etc. He/she is entitled to freedom of thought, conscience and religion. $\mathrm{He} / \mathrm{she}$ has right to freedom of expression, movement and association, freedom from discrimination, etc.

The fact on ground shows that a Nigerian child is a communal child that must respect and obey an elder and accept corrections from any member of the society. But his/her dignity is in most circumstance trashed on the ground. His/her freedom of expression, movements and association is not assured. This child is a compulsory community worker or baby sitter. The child comes from a large family size of about 6-12 children who lacks adequate welfare and care and is given out as a maid or servant to any family that cares for one. This child is subjected to any kind of labour ranging from employed labour to hawking and breadwinner for families. This child is 
exposed to dangerous diseases of different kinds and even to rape in some circumstances. In other circumstances he/she is made to beg for arms and carter for himself/herself ('Almageri'). Above all, his right to education is a luxury that is hard to come by. With the school age, the child is meant to hawk, hunt for food or go into apprenticeship to fend for the family. The ones that attempt to go to school are sent back for non-payment of fees and lack of school materials.

The Nigerian child is also one who is born and bred in a nuclear and extended family system; who has uncles, aunties, cousins, nephews, nieces, etc. He/she is a child in a community that works for the coherence of the community. He/she regards his town's or village people as his/her own people. Communally, a person in need is helped to stabilize as each person is a 'brother' or 'sister'. He assists the father every morning to pour libation to the gods and ancestors for good life and progress of every member of the family, kindred, village or town.

\section{Concepts of a Nigerian (Child)}

The 1999 constitution of the Federal Republic of Nigeria section 25 (a-c) described the following as Nigerians by birth:

- $\quad$ Every person born in Nigeria before the date of independence, either of whose parents or any of whose grandparents belongs or belonged to a community indigenous to Nigeria.

- Every person born in Nigeria after the date of independence either of whose parents or any of whose grandparents is a citizen of Nigeria.

- $\quad$ Every person born outside Nigeria either of whose parents is a citizen of Nigeria.

The constitution further stated in section 26 that one can be a Nigerian by registration if the President is satisfied that the person is of good character, shows clear intentions of the desire to be domiciled in Nigeria and takes the Oath of allegiance as prescribed; or that one can be a Nigerian by Naturalization after fulfilling the requirements which included residing in Nigeria continuously for a period of 15 years. (1999 constitution of the Federal Republic of Nigeria)

Bibi (2005) described a true Nigerian as one who is resilient, filled with hope for a good tomorrow. A good Nigerian believe in justice, believe in God absolutely even when robbed by the leaders every day. A true Nigerian believes that (by) working hard, one day he/she will become somebody in the society; believes in hard work, believes that he must continue striving no matter how difficult, even dying in the process. A true Nigerian believes that if he does not make it in this life, his offspring would and will carry on the glory of his family.

According to Hot-Angel (2005), a true Nigerian is whoever calls someone that is not related to him or her aunty/uncle. According to Egenti (2011), for a country like Nigeria parading more than 250 ethnic groups and boasting of over 510 languages, it should not be a surprise that it's politics is hostage to tribal feelings as most people identify with and are loyal to their ethnic groups rather than the country. As a result, people are identified by their tribes: you hear "that is a typical Yoruba man" or "that must be an Igbo woman" "that "or " must be a Fulani" or "that must be a Calabar girl" etc. Everybody is first an indigene of an ethnic group and then a Nigerian last.

Egenti further stated that Nigerians still see Nigeria as a colonial joinery, a mere geographical expression. In other words, people are questioning the idea that people of different ethnic and religious background can be equal citizens with them in the same country. People are still finding it hard to accept other Nigerians of different ethnic group as equal citizens and stakeholders

\section{The Nigerian Child: an Appraisal}

The constitution of any nation stipulates the fundamental rights, laws and customs that describe a particular group of people. According to Okwodu (1978), it is a body of laws and conventions which describe the proper form of the government and defines its rights and duties. By implication, the constitution of the Federal Republic of Nigeria is an accepted document that describes Nigeria and her peoples' way of life and identity. The constitution described a Nigerian child as 
- Every person born in Nigeria before and after the date of independence either of whose parents or any of his grandparents belongs to a community indigenous to Nigeria.

- $\quad$ Every person born outside Nigeria either of whose parents is a citizen of Nigeria.

- One who is a Nigerian either by registration or naturalization.

Do these stipulations actually identify a Nigerian? Identity is a mark that distinguishes one from another, but must be with the person to mark him or her out from another. These constitutional stipulations do not identify a black man or any man standing on the streets of London. By implication, it has not typically given identity to a Nigerian. The question, who is a Nigerian or what makes a Nigerian, Nigerian, is therefore not given a satisfactory answer. The principle of identity rests immediately on the concept of being. A 'being' is and 'non-being' is not. The truth of this judgment is intuitively clear to the mind without the need of any demonstration. Bittle (1938) stated, whatever is, is, and whatever is not, is not. Everything is what it is: Everything is its own being: being is being, and not-being is not being. The above constitutional stipulations have not stated what makes a Nigerian child a Nigerian as mere 'birth' cannot entirely describe a Nigerian. According to Egenti (2011), Nigerians are identified by their tribes ... Everybody is first an indigene of an ethnic group and then a Nigerian last. This description sees Nigerian as a heterogeneous collection of individuals and not a homogeneous entity. By implication there exists a homogeneous entity but according to tribes. Therefore, the identity "Nigerian" is tribal in nature. There cannot then be a Nigerian child, but an Igbo child, Yoruba child, Hausa child, Fulani child, Efik child etc.

Bibi (2005) and Hot-Angel (2005) tried to describe a Nigerian as resilient, hard working and full of hope for tomorrow and accommodating. This is an attempt to identify a Nigerian, an identity that marks him or her out from others. Who is a Nigerian (child)?

\section{A Nigerian in Perspective}

That Nigeria is made up of too many ethnic nationalities is immaterial. Rather there are certain characteristics that are common to all irrespective of the tribe and tongue. They all live in an ontological world Nigeria. By implication, every Nigerian is a "Being in the Nigerian world". All the ethnic nationalities in Nigeria are black in colour which also makes them African. A Nigerian child is born black, but becomes a Nigerian. Every tribe or ethnic group in Nigeria is nepotic and aspires only for the good of his relation against any other. For instance, an Igbo man sees another Igbo man as a brother/sister outside the Igbo race. Also, a typical Nigerian fights a war in favour of his tribe, tongue and relations. Above all, there is an acceptance of the 'other'. Every tribe is communal in nature and accepts anyone who relates with him/her in their native custom. This same instinct is not different in religion. You are a brother or sister in so far as you profess the same religion even irrespective of tribe/ethnic nationality. The relationship with the other, do not even end with death. There is still the belief that a link still exist with the dead and so they are buried inside the household. Even a case of accident where one is burnt to ashes, the ashes are collected and buried in the household.

Therefore, the metaphysical Nigerian world is a world of "Being-with-Others". The self in a Nigerian child is essentially towards others, i.e. a self in relation to others. This is buttressed by Okoro (1993) where he said that individuals become real only in relationship with others, in a community or group. It is the community which makes the individual, to the extent that without the community, the individual has no existence. The Nigerian self is a 'we-existence'. A Nigerian child therefore is a 'Being-with' in the Nigerian world irrespective of his place of abode.

\section{Factors Affecting the Nigerian Child}

The 'Being-with' in the Nigerian world has been destabilized by so many factors which have hampered his/her maximum development. Among these factors include poverty, negative change in value system, politics, civilization (devaluation of culture) etc. 
Poverty has derailed the Nigerian child. So many Nigerian children live in families who earn below N100 (one hundred naira) per day, whereas the minimum cost of feeding per day per person is about N300 (three hundred naira). This has limited the potentialities of the Nigerian child. Many have been exposed to so many inhuman and immoral acts to survive.

Negative change in the value system has also affected the Nigerian child. The national ethics of Nigeria according to the 1999 constitution of the Federal Republic of Nigeria section 23, shall be discipline, integrity, dignity of labour, social justice, religious tolerance, self reliance and patriotism. This ethics has been turned to the negative and the environment created for the Nigerian child is that of corruption, indiscipline, injustice, religious war, etc. Anameze (1998) observed that in the present Nigerian society, intellectual values do not seem to be sufficiently appreciated and rewarded. Money and what money can buy are preferred to academic excellence in our society. Igwe (2005) stated thus; what else would be expected from children who know that their fathers are corrupt, that they amass wealth by all sorts of dubious means, that with the older generation, greed, incompetence and the philosophy of maximum gain for minimum input seem to be our national way of life. This environment destroys the metaphysics of the Nigerian world and the 'Being-with' is gradually dying away. The situation of the Nigerian child now is what can be called dog eat dog!

Our culture of communalism is lost under the guise of civilization. Cultures that abhor evil now praise evil. The culture of helping the poor and needy has been eroded. Again, the 'Being-with' is lost.

Politics in Nigeria is a do or die affair and the winner takes it all. Through politics and governance, a group enriches themselves from the common purse thereby depriving a greater majority of people their benefits and future. Again, the nature of 'we-existence' is gradually being destroyed.

These and other problems seriously destabilize the Nigerian child and make him/her prone to vices as against virtue.

\section{Recommendations}

In the light of the above discussions, there is need to make Nigerians:

- Re-understand themselves as 'Being-with' that is meant to live with others and together there will be better development.

- Manage the abundant natural resources for the good of all bearing in mind that together and with each other, there is existence.

- Know that a good value system improves our Nigerian world. Our ethics is in line with our being with the other and therefore should be adhered to.

- Understand that our good cultures should be maintained because they emanated from our being and therefore brings us close to each other.

\section{Conclusion}

The Nigerian child is a factor of 'Being-with' which is a byproduct of culture, rooted as it were in our extended family system and in the essential religious world view of Nigerians.

However, 'Being-with' in its qualities and dimensions can be lost, re-gained or even lost forever because of the environment we create from the neo-civilization.

\section{References}

1999 constitution of the Federal Republic of Nigeria

Anameze, L.N. (1998) Students Guide to Academic Success. Enugu: CPA and Gold Production.

Bibi (2005) Who is a True Nigerian retrieved from http://www. nairaland.com/nigeria/topic-2081.0.html

Bittle, C.N. (1938) The Domain of Being. America: The Bruce Publishing Company Milwaukee. 
Egenti, H.I. (2011) Who is a Nigerian: Identity Politics, Zoning and Compatriotism. Retrieved from http://www.nigeriavillagesquare.com/articles/guest-articles/qwho-is-a-nigerianq-identitypoliticszoning-andcompatriotism.html

Hot-Angel (2005) Who is a True Nigerian. Retrieved from http://www.nairaland.com/nigeria/topic2081.0.html

I gwe, S.O. (1985) Professional Handbook for Teachers. Owerri: New African Publishing Company Ltd.

Okoro, C.B. (1993) What is to be African: Essay on African Identity. Enugu: CECTA (Nigeria) Ltd 
